\title{
MICROBIOLOGICAL AND PHYSIO-CHEMICAL STUDIES OF THE DRAIN WASTEWATER
}

(Received:6.11.2013)

\author{
By \\ M. M. Ahmed*，G. Abd El- Fatah, M.S. Khalil * and M.Z. Sedik \\ Microbiology Department, Faculty of Agriculture, Cairo University \\ *EEAA- Egyptian Environmental Affairs Agency
}

\begin{abstract}
For the last few years, a great interest has been shown for research on aquatic macrophytes as good candidates for pollutant removal or even as bioindicators for heavy metals in aquatic ecosystems.

The agricultural drainage water contains pesticides, fertilizers, effluents of industrial activities, effluents of domestic wastewater and runoffs. In addition, the sewage effluents supply the water bodies and sediment with huge quantities of organic and inorganic anions and heavy metals.

When the wastewater or effluent is discharged into a natural stream, the organic matter is converted into ammonia, nitrates, sulphates, carbon dioxide etc. by bacteria. Most of the heavy metals become bound to the particles in sediment, but a small quantity becomes dissolved in water and can spread widely in the food chains.

The present study aimed to monitor water quality at a branch agricultural drain in east Delta Region by measuring some physical, chemical and microbiological parameters at the beginning and the end of the drain during two years 2010/2011 and 2011/2012 in January and July of each year.

Results of the drain wastewater showed that, the temperature ranged $15-17^{\circ} \mathrm{C}$ in winter and $27-31^{0}$ $\mathrm{C}$ in summer. $\mathrm{pH}$ values ranged 7.0 - 9.0 in both years. For Dissolved Oxygen DO, the values ranged 62.0 to $65.6 \%$ in July. Moreover, the high increase in Biological Oxygen Demand BOD was found in the $1^{\text {st }}$ year at January. The Biological Oxygen Demand $\div$ Chemical Oxygen Demand BOD/COD index ranged 0.63 to 0.83 in the two studied years. Also, the $\mathrm{Mn}$ and $\mathrm{Cd}$ concentrations were high, while $\mathrm{Cu}$ and $\mathrm{Zn}$ were less than that recorded at EPA (1986).

The microbiological determination of the drain also, revealed that microbial counts were high in July and reached $1.3-1.7 \times 10^{7} \mathrm{CFU} / \mathrm{ml}$ wastewater. Coliform counts reached $7.0-11.0 \times 10^{6} \mathrm{CFU} / \mathrm{ml}$ in summer. The FC/FS ratio was > 4.0. This ratio means that the pollution of the drain is of feacal type pollution.
\end{abstract}

Keywords: microorganisms, nutrient conversions, pollution, self purification, water hyacinth, wastewater.

\section{INTRODUCTION}

The use of urban wastewater in agriculture is a centuries-old practice that is receiving renewed attention with the increasing scarcity of fresh water resources in many arid and semi-arid regions of the world. Driven by rapid urbanization and growing wastewater volumes, wastewater is widely used as a low-cost alternative to conventional irrigation water as it supports livelihoods and generates considerable value in urban and peri-urban agriculture despite the associated health and environmental risks (Scott et al., 2004).

In Egypt, agricultural drainage water reuse is well developed, particularly in the Nile Delta region. Drainage water is one of the valuable water resources in Egypt, created by the intensive and large irrigation/drainage systems. However, the drainage reuse practices is threatened by the deteriorating drain water quality due to municipal and industrial wastewater pollution (Abdel-Azim and Allam 2004).

When wastewater or effluent is discharged into a natural stream, the organic matter is converted into ammonia, nitrates, sulphates, carbon dioxide etc. by bacteria. In this process of oxidation, the dissolved oxygen content of natural water is utilized and thus, deficiency of dissolved oxygen is created. As the excess organic matter is stabilized, the normal cycle will be in a process known as self-purification where in the dissolved oxygen is replenished through reaeration by 
atmospheric oxygen of wind (Water and Wastewater, 2000).

Self-purification of streams largely depends upon currents, (as rapids, whirlpools, waterfalls and turbulent flow) which will readily disperse the wastewater in the stream, preventing local accumulation of pollutants. High velocity accelerates reaeration and reduces the concentration of pollutants. High velocity improves reaeration, reduces the time of recovery, though the length of the stream affected by the wastewater is increased (Water and Wastewater, 2000).

In wastewater treatment, there are three types of bacteria used to treat the waste water which is also refined by the treatment plant, aerobic, anaerobic and facultative types (Kyocp, 2012). Aerobic bacteria use the free oxygen in the water to degrade the pollutants in the incoming wastewater into energy and used for growth and reproduction. In most cases, the oxygen has to be added mechanically to the wastewater through the use of aerators in the aerated section. With a normal influent load of pollutants, the dissolved oxygen content in the aerated section of most plants should be kept between 3.0 to $5.0 \mathrm{mg} / \mathrm{l}(\mathrm{KY}$ OCP, 2012). But, anaerobic bacteria are normally used in an anaerobic digester to reduce the volume of sludge to be disposed of and to produce methane gas.

In the last three decades there was a special interest in using the biological methods in the waste water treatment, whose application as of natural of tertiary processing of effluents provides the effluents of required quality in an economically acceptable way in the technically simple structures. The capacity of water hyacinth (Eichhornia crassipes) as a very promising plant with tremendous application in wastewater treatment has already been proved (Trivedy, 2001, Jafari and Trivedy, 2005).

\section{MATERIAL AND METHODS}

\section{A- Study site}

This study was carried out in a branch agricultural drain in Mansoura, Dakahlya Governorate, Egypt. From our observation, the pollution of surface and subsurface water has increased due to domestic and agricultural wastewater, where intensive multiple crops (vegetablies and crops) farming is practiced along the drain. Thus, the wastewater discharge will directly impact the performance of water quality at the agriculture drain.

The characters of the study site are found in
Fig.1. map of drainage water in Eastern Nile Region at Dakahlia Governorate (FAO, 2005).

\section{B - Materials}

\section{Wastewater samples}

Four wastewater samples were collected in January and July in the two successive years 2010/2011 and 2011/2012. Samples were taken from the beginning and the end of the drain $30 \mathrm{~cm}$ subsurface of water and filled in 4.01 sterilized glass bottles. Samples were kept in icebox during transfer to the lab. Wastewater samples were kept in refrigerator at $4^{\circ} \mathrm{C}$ until microbiological and chemical determinations were conducted.

Nine water quality parameters were measured and analyzed. Microbiological determinations were: total microbial counts, total coliform counts, fecal coliform counts and fecal streptococci counts. Also, chemical determinations included dissolved oxygen (DO), Biological Oxygen Demand (BOD- 5 days, $20^{\circ} \mathrm{C}$ ), Chemical Oxygen Demand (COD), anions (nitrate, ammonia and phosphate) concentrations, as well as the heavy metal (copper, manganese, cadmium, zinc and iron) concentrations.

\section{C - Methodology \\ 1. Physical parameters \\ 1.1. Temperature}

Temperature was measured directly by a thermometer attached to water samples.

\section{2. $\mathrm{pH}$}

Hydrogen ion concentration ( $\mathrm{pH}$ value) was measured using $\mathrm{pH}$ meter (ORION, USA) model 420A, connected to epoxy $\mathrm{pH}$ electrode calibrated at 4 and $7 \mathrm{pH}$ values.

\section{2-Chemical parameters \\ 2.1. Organic chemical parameters \\ 2.1.1. Dissolved Oxygen (DO)}

Dissolved oxygen was measured using dissolved membrane oxygen meter (WTW) model (OXI 315i, Germany) and oxygen correspond sensor (WTW) model (DuroX325, Germany)

\subsubsection{Biological Oxygen Demand (BOD)}

BOD was determined by Manometric BOD Oxitop system. Dark brown bottles were filled with $426 \mathrm{ml}$ of water samples, supplied with magnetic stirrer and digital monitor on the mouth of the bottle, and incubated at $20{ }^{\circ} \mathrm{C}$ for 5 days.

\subsubsection{Chemical Oxygen Demand (COD)}

COD was determined by dichromate reflux method where $2 \mathrm{ml}$ of water sample were added to a small glass tube containing a mixture of potassium dichromate, mercuric sulfate, silver sulfate and sulfuric acid, and refluxed at $150^{\circ} \mathrm{C}$ for $90 \mathrm{~min}$. The intensity of the formed complex was measured by the visible Spectrophotometer 
(HACH- 2000, USA).

\subsection{Inorganic chemical parameters}

Copper, manganese, cadmium, zinc and iron concentrations in each sample were measured by Inductively Coupled Argon Plasma Optical Emission Spectroscopy (ICP-OES) (Perkin Elmer Optima-3000 Redial, USA).

\section{Chemical compounds}

Nitrate concentration was measured by Ion Chromatography (IC-METROHM) model (DX500 chromatography system, USA). Ammonia was measured using ammonia selective electrode, ORION model 95-12 attached to a bench top Ion analyzer, ORION model (EA940, USA) with built-in stirrer. Total phosphours was measured using spectrophotometer, model (Vislfias lambda20, USA).

\section{Microbiological parameters}

All bacterial parameters were examined by using the filter membrane technique (FM) except the total microbial count by the spread plate method. All the procedures for the detection of different bacteriological parameters are described in the Standard Methods for Examination of Water and Wastewater (APHA, 1995). To reach a countable number of the respective parameter, 100 $\mathrm{ml}$ of each type of water sample were transferred to a stainless steel filter membrane funnel and filtered via a sterile filter membrane(cellulose nitrate membrane of uniform pores diameter of $0.45 \mu \mathrm{m}$ pore size, Gel man, USA) by using negative pressure. Each filter membrane was transferred on the surface of a corresponding solidified agar medium previously poured into a sterile Petri plate by the aid of a sterile forceps. All the examined samples were tested for the enumeration of the following parameters:

\subsection{Total microbial count}

Plate count agar medium was prepared. Serial dilutions of water samples were made and $0.1 \mathrm{ml}$ of each dilution was pipetted onto the surface of the pre-dried agar plates. Using the spread plate method, with plastic sterile loop, the inocula were distributed over the surface of the media and allowed to be completely absorbed into the media before incubation. The inoculated plates were divided into two sets, one was incubated at $35^{\circ} \mathrm{C}$ for $48 \mathrm{~h}$ and the other was incubated at $22^{\circ} \mathrm{C}$ for $48 \mathrm{~h}$. The results were recorded as $\mathrm{CFU} / \mathrm{ml}$ (APHA, 1995).

\subsection{Enumeration of Total coliform}

$100 \mathrm{ml}$ of the drainage water samples were filtered through nitrocellulose membrane filter $(0.45 \mu \mathrm{m}$ pore size). After filtration and removing the funnel, a membrane was aseptically placed (grid-side up) on the surface of (LES-Endo) agar medium. Air bubbles were avoided between the inoculated filter and medium surface. Plates were inverted and incubated at $35^{\circ} \mathrm{C}$ for $24 \mathrm{hr}$. All the pink color colonies with metallic shine were counted by using colony counter. The count was calculated for each sample and recorded as CFU/100ml of sample (APHA, 1995).

\subsection{Enumeration of fecal coliform (FC)}

As previously mentioned, filter membrane technique was used for the enumeration of fecal coliforms. After filtration of $100 \mathrm{ml}$ of water sample and removing the funnel,the membranes were placed on the surface of prepared modified fecal coliform (M-FC) agar plates. The plates were incubated at $44.5^{\circ} \mathrm{C}$ for $24 \mathrm{~h}$ at an inverted position. Blue shade colonies were counted and calculated as CFU/100 $\mathrm{ml}$ of the original sample (APHA, 1995).

\subsection{Enumeration of fecal streptococci}

After filtration of $100 \mathrm{ml}$ of water sample, filter membrane was placed on the surface of modified Enterococcus (M-Enterococcus) agar. The plates were incubated at $35^{\circ} \mathrm{C}$ for $48 \mathrm{~h}$ at an inverted position. Red to Pink colonies were counted and calculated as CFU/100 $\mathrm{ml}$ of the original sample (APHA, 1995).

\section{RESULTS AND DISCUSSION 3.1. Physical parameters 3.1.1. Temperature}

Fig. (2) Shows the mean temperatures recorded in two points tested in the drain during January and July in the two studied years. The results revealed that, the temperature ranged $16-22{ }^{\circ} \mathrm{C}$ in January and $28-32^{\circ} \mathrm{C}$ in July. These data mean that, in winter the surface water can get cold, thus the surface water becomes denser than the deeper, the drain turns when colder surface water sinks to the stream bottom. These results are in agreement with the data recorded by USGS (2013), and with the data reported by Earth Force (2010) which recorded that, temperature can affect dissolved oxygen level in water, photosynthesis, animal survival and sensitivity to toxic wastes and diseases.

\subsection{2. $\mathrm{pH}$}

The $\mathrm{pH}$ of the wastewater could indicate the general pattern of the basic level of the drain. Fig. (3) Shows the mean $\mathrm{pH}$ recorded in the drain in the two points tested (beginning and end) and two years (2010/2011 and 2011/2012). The data indicated that, $\mathrm{pH}$ values were 7.6 except in July 2010/2011 (7.8).

The $\mathrm{pH}$ values obtained are in agreement with the data reported in water and wastewater(2000). The $\mathrm{pH}$ range suitable for the water and wastewater 


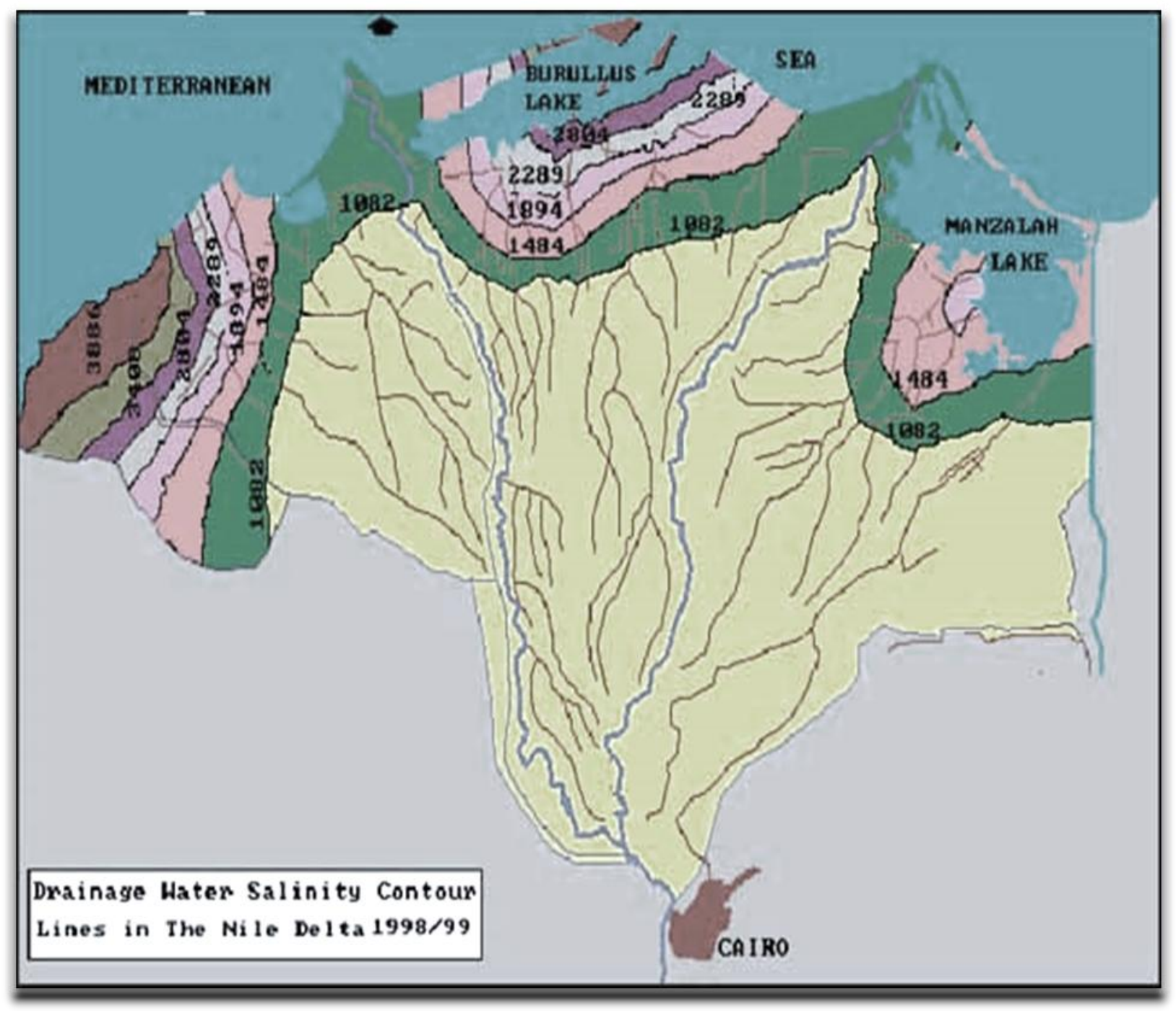

Fig.(1): Map of drainages water in Eastern Nile Region at Dakahlia Governorate (FAO, 2005).

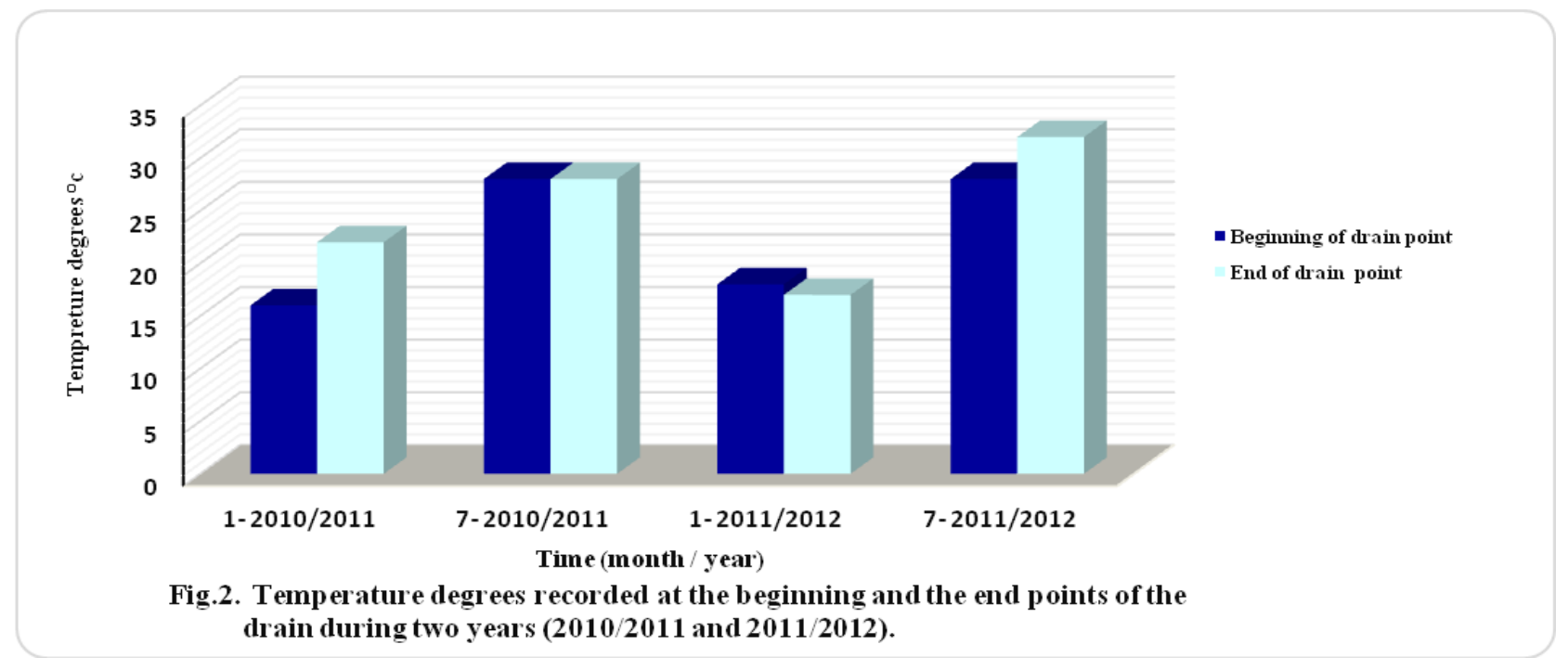




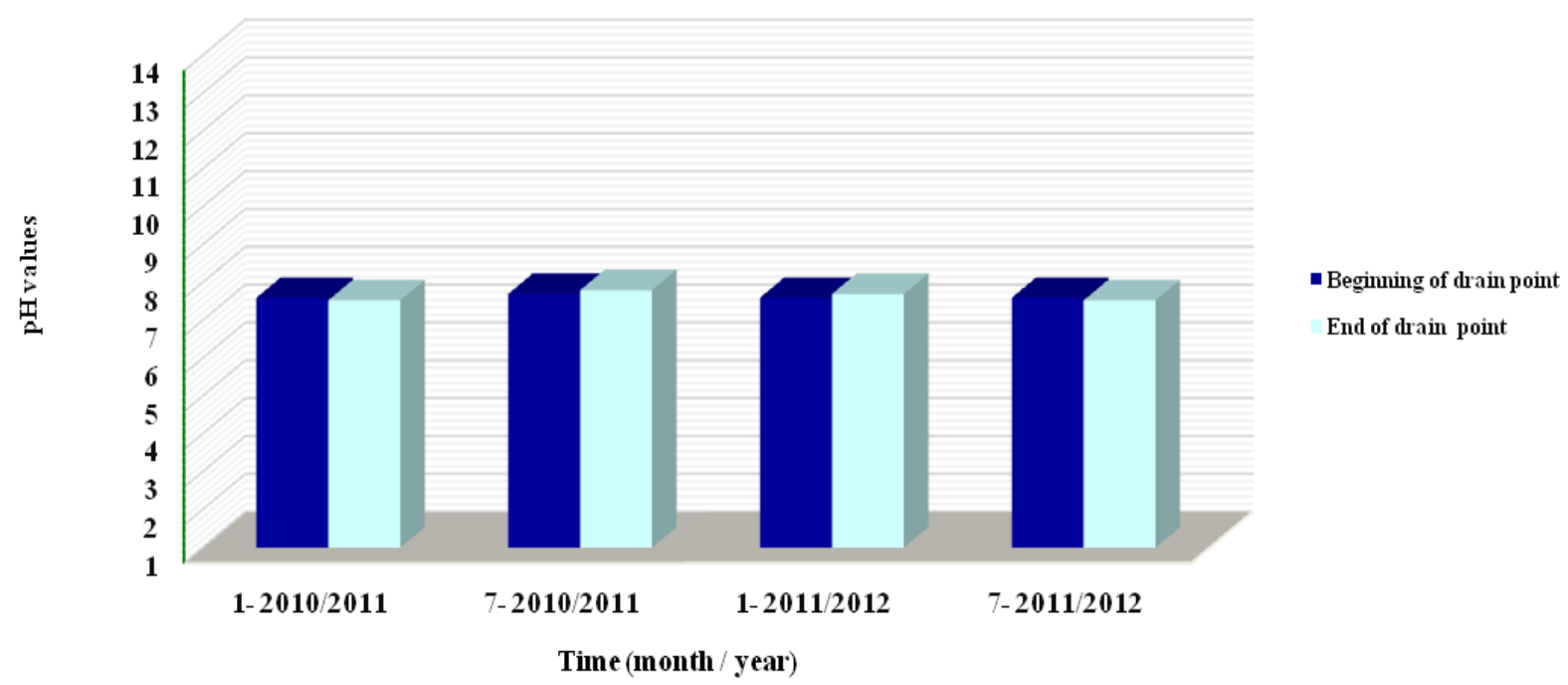

Fig.3.pH values recorded at the beginning and the end points of the drain during two years $2010 / 2012$.

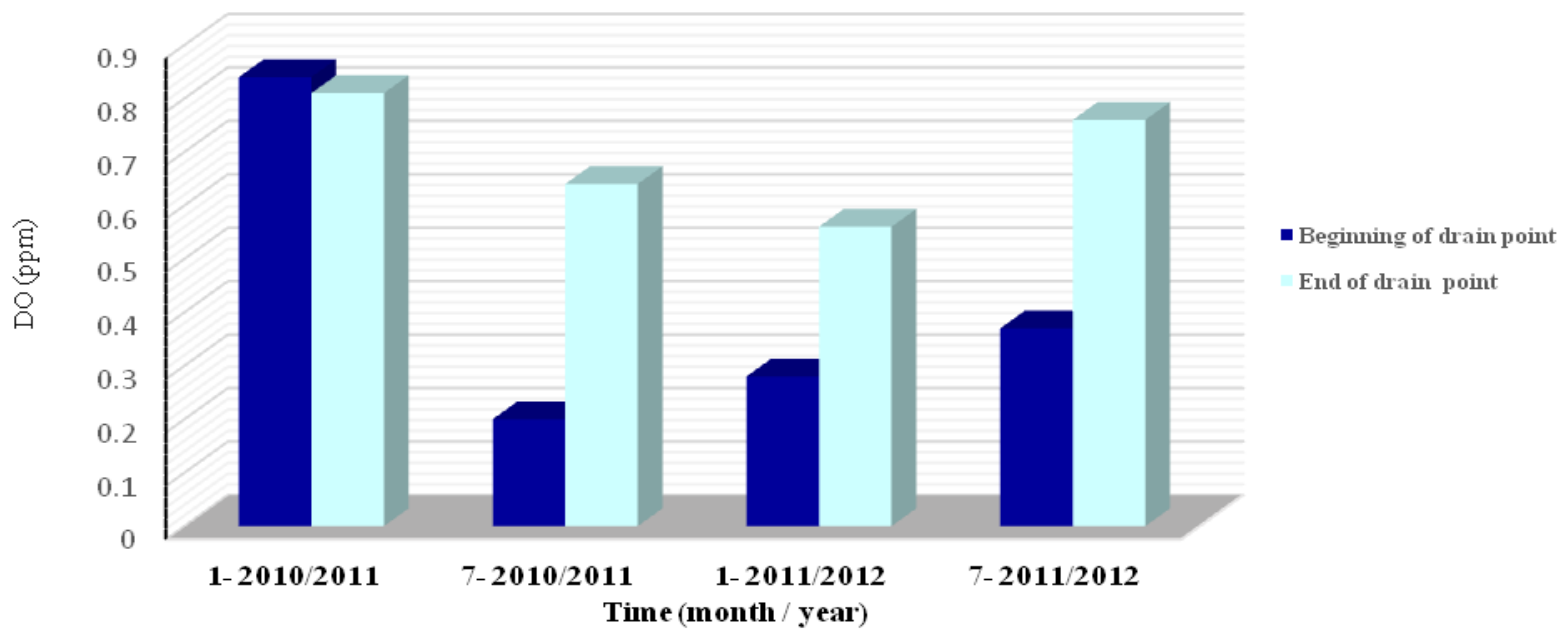

Fig.4. Dissolved Oxygen at the beginning and the end points of the drain during the two years $2010 / 2011$ and $2011 / 2012$.

is 7, while survival and nourishment of most biological life is quite narrow and critical, i.e. 6.5 to 8.5 . But, with extremely high or low $\mathrm{pH}$ levels (for example 9.6 or 4.5 ), the water becomes unsuitable for most organisms and biological treatment.

Water $\mathrm{pH}$ in the drain ranged between 7.5-7.8 which is a semihigh. Padmavathi and Prasad (2007) showed that high $\mathrm{pH}$ levels in pond water are associated with algal blooms. Also, high $\mathrm{pH}$, indicating excessive alkalinity, can also be harmful.

\subsection{Chemical parameters}

\subsubsection{Organic chemical parameters}

\subsubsection{Dissolved Oxygen (DO)}

Data presented in Fig. (4) shows the DO of the drain. The results obtained indicated that, the DO was low in January (2010/2011). In addition, the DO was high at the end of drain than the beginning point tested. The percentage of increase in DO ranged between 220-105.4\% in July in the $1^{\text {st }}$ and the $2^{\text {nd }}$ years tested.

\subsubsection{Biological Oxygen Demand (BOD)}

Data recorded in Fig. (5) show a decrease in BOD levels which occurred in the end of the drain in all months and years tested. The high decrease was recorded in the $1^{\text {st }}$ year in January. Where, the decrease percentage reached $(-83.9 \%)$. This action in BOD may be due to winter clog.

These results are in agreement with the data recorded by Earth Force (2010), which reported that the greater values means less oxygen which led to aquatic organisms become stressed, suffocate, and die. 


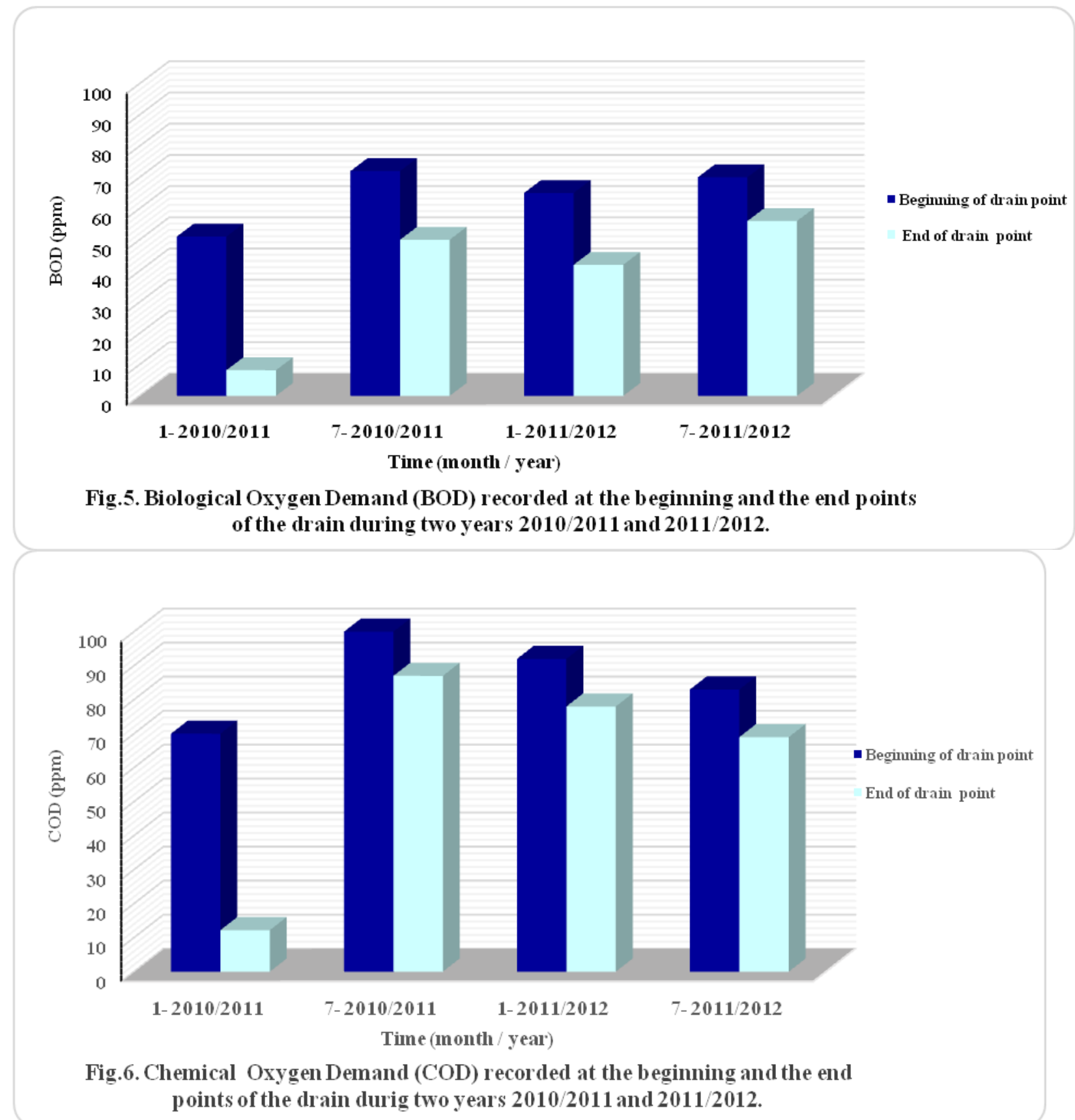

\subsubsection{Chemical Oxygen Demand (COD)}

Fig. (6) shows COD levels in the drain during the two studied years. The same trend of BOD was recorded with COD during the two months and years tested. The data revealed that, the COD values were high in the summer time and in the beginning of the drain than the winter season and the end of the drain.

COD values ranged between 70 to $92 \mathrm{ppm}$ at the beginning and 12.2 to $78 \mathrm{ppm}$ at the end in the winter season. But, values reached 83 to $101 \mathrm{ppm}$ at the beginning and 69 to $87 \mathrm{ppm}$ at the end of the drain in summer. Also, highly reduced percentage was recorded in January 2010/2011, where, the decrease percentage reached $(-82.57$ $\%)$. This effect was due to winter clog.

The BOD/COD index of the drain at the beginning and at the end of drain during the two years was recorded in Table (1).

The data obtained on the BOD/COD index showed that the index ranged between 0.63 to 0.83 irrespective of to the season tested. This means that, the waste was fairly biodegradable and could be effectively treated biologically (Earth force, 2010).

\subsubsection{Inorganic chemical parameters}


Table (1): BOD/COD Index in El-Gabbada Drain at the begining and at the end points of the drain during the two years 2010/2011 and 2011/2012.

\begin{tabular}{|c|c|c|c|l|}
\hline Month/Year & $\begin{array}{c}\text { At the drain } \\
\text {-mean BOD } \\
\text { (ppm) }\end{array}$ & $\begin{array}{c}\text { At the } \\
\text { drain- } \\
\text { mean COD } \\
\text { (ppm) }\end{array}$ & $\begin{array}{c}\text { Measurment of } \\
\text { Biodegradability } \\
\text { Index } \\
\text { (BOD/COD) }\end{array}$ & \multicolumn{1}{|c|}{$\begin{array}{c}\text { Limitation of Biodegradability Index } \\
\text { (BOD/COB) (Earth force, 2010). }\end{array}$} \\
\hline $1-2010 / 2011$ & 29.60 & 41.10 & 0.72 & $\begin{array}{l}\text { Limitation of Biodegradability Index } \\
\text { (BOD/COB) (Earth force, 2010). }\end{array}$ \\
\hline $7-2010 / 2011$ & 61.00 & 94.00 & 0.65 & $\begin{array}{l}\text { - If BOD/COD is > O.6 then the waste is fairly } \\
\text { biodegradable and can be effectively treated } \\
\text { biologically. }\end{array}$ \\
\hline $1-2011 / 2012$ & 53.50 & 85.00 & 0.63 & $\begin{array}{l}\text { - If BOD/COD ratio is between 0.3 and 0.6, then } \\
\text { seeding is required to treat it biologically. }\end{array}$ \\
\hline $7-2011 / 2012$ & 63.00 & 76.00 & 0.83 & $\begin{array}{l}\text { - If BOD/COD is < 0.3 then it cannot be treated } \\
\text { biologically }\end{array}$ \\
\hline
\end{tabular}

In the Egyptian irrigation system, the main source of $\mathrm{Cu}$ and $\mathrm{Pb}$ are industrial wastes as well as algaecides for $\mathrm{Cu}$, while $\mathrm{Cd}$ is from the phosphatic fertilizers used in crop farms (Mason, 2002). Also, El- Sayed et al. (1991) reported that, the drain water of the Nile Delta has dissolved humic substances in their surface water which can be considered as sites for heavy metal storage.

\subsubsection{Copper $(\mathrm{Cu})$}

Tables (2) showed that, the removal rates of copper were higher in the winter than in the summer (2010/2011), where, the rates reached ($68.75 \%)$ and $(-17.65 \%)$, depending upon the month tested, respectively.

In spite of that, some microorganisms require copper-containing enzymes to drive certain vital chemical reactions. Researchers believe that excess copper has the potential to disrupt cell function both inside the cells and in the interstitial spaces between cells, probably acting on the cells' outer envelope (Encyclopedia, 2012 and 2013).

\subsubsection{Manganese (Mn)}

Table (2) reveals the removal rates of manganese in the drain. The results showed the same trend of removal rates with copper, where the rate was higher in winter than in summer.

Manganese is present in the soil as a result of mineral weathering and atmospheric deposition, originating from both natural and anthropogenic sources.

Manganese concentration in the water is primarily controlled by $\mathrm{pH}$ and redox conditions, where solubility increases under acidic as well as under anaerobic conditions. In neutral conditions, the redox potential has a stronger influence on manganese mobility than $\mathrm{pH}$. The concentration of manganese under aerobic conditions, typical of shallow aquifers and surface water, is generally low and as a rule does not reach detection limits.
The reason is that in aerobic conditions, manganese is found in its stable oxidized form, generally as $\mathrm{MnO}_{2}$.

The reduction reactions follow a sequence in which oxygen is removed first, followed by nitrate and manganese. Progressively more reducing conditions lead to the reduction of iron followed by sulphate. In these anaerobic conditions, manganese is released from minerals and reduced to its more soluble form, Mn (II). This form is apparently the most soluble one in most waters. Much higher manganese concentrations are therefore commonly found in anaerobic ground waters than in aerobic surface waters or shallow ones (Nadask'a et al., 2013).

\subsubsection{Cadmium (Cd)}

The removal rate of cadmium recorded in the drain is presented in Table (2). The data show that, the rate of cadmium removal reached $(-80 \%)$ in January at the $1^{\text {st }}$ year and decreased to $(-16.7 \%)$ in the $2^{\text {nd }}$ year. While, in the summer time the opposite figure was detected, where the concentrations of cadmium were low in the beginning of drain and increased in the end of drain. The percentage of increase reached $(28 \%)$ and $(8.3 \%)$ in the $1^{\text {st }}$ and the $2^{\text {nd }}$ years, respectively.

Cadmium may be entering water from waste disposal plants. These data are in agreement with the data recorded by Bull (2010), who stated that cadmium is a metal that is widely distributed in the earth's crust (soil and rocks), air and water. Larger amounts of cadmium are released from human activities such as using phosphate fertilizers, burning coal, making iron, steel and cement and disposing household waste. Also, cadmium may enter water and soil in the waste from industries, waste disposal plants, or as a result of leaching from landfill sites. It may also leach into water supplies from pipes. 
Table(2): Comparison between removal rate percentage for Heavy Metals at the beginning and at the end of El-Gabbada drain durig two years 2010/2011 and 2011/2012.

\begin{tabular}{|c|c|c|c|c|}
\hline & January 2010/2011 & July 2011/2012 & January 2011/2012 & July 2011/2012 \\
\hline Cu & -68.75 & -23.08 & -17.65 & -04.76 \\
\hline Mn & -41.18 & -04.76 & -16.67 & 45.45 \\
\hline Cd & -80.00 & 28.57 & -16.67 & 08.33 \\
\hline Zn & -90.00 & 09.09 & -16.67 & 08.33 \\
\hline Fe & -89.58 & -09.68 & -04.17 & -32.08 \\
\hline
\end{tabular}

Moreover, IFA (2013) recorded that, cadmium is toxic to plants, animals and microorganisms. Being cadmium is persistent; it cannot be broken down into less toxic substances in the environment. The degree of bioavailability and potential for its effects varies depending on the form of cadmium and the $\mathrm{pH}$.

\subsubsection{Zinc (Zn)}

Data presented in Table (2) show the removal rates of zinc in the drain. Rate of removal was high and reached $(-90 \%)$ and $(-16 \%)$ in the winter while it was very low in the summer where the recorded data reached (9\%) and (8.3\%), respectively.

The high ratio of zinc in the drain water may be due to fossil fuel combustion, mine waste, phosphate fertilizers, limestone, manure, sewage sludge, and particles from galvanized surfaces. So, zinc can reach water from the soil (Encyclopedia, 2012 and 2013).

\subsubsection{Iron $(\mathrm{Fe})$}

Table (2) shows the removal rates of iron in the drain. The results indicated that, the removal rates take the same trend with zinc removal. This meaning that the rate was high in winter and low in the summer.

The comparison between the permissible limits according of USEPA (1986) and the data obtained about the heavy metals concentration at the drain (beginning and end points tested) showed that, $\mathrm{Mn}$ and $\mathrm{Cd}$ levels were high while, both of $\mathrm{Cu}$ and $\mathrm{Zn}$ levels were low compared with permissible limits. But in the case of Fe, the results showed that the Fe concentration was high only in July 2011/2012 than the permissible limits (Tables 3 and 4).

\subsection{Chemical Compounds}

Large quantities of nutrients in water can cause excessive growth of vegetation such as algae and larger aquatic plants. If present in sufficient quantity, aquatic vegetation can cause the dissolved oxygen in water to change from low values at night when vegetation takes in oxygen from the water, to high values during the day when the vegetation is photosynthesizing and producing oxygen (Moss, 2012).

\subsubsection{Nitrate $\left(\mathrm{NO}_{3}-\mathrm{N}\right)$ and Ammonia $\left(\mathrm{NH}_{3}-\mathrm{N}\right)$}

Table (5) shows the nitrate and ammonia values recorded for the same two points tested in the same seasons as well as the removal rate (\%). The data indicated that, the highest removal rate (\%) of nitrate was recorded in the winter and ranged between $(-38 \%)$ and $(-21.5 \%)$. But, in the summer, the rate decreased and ranged between ($19.9 \%)$ and $(5.2 \%)$, respectively.

While, in the case of ammonia removal rate, the values were so high and reached (-92.9\%), ($24 \%)$ and (-19.2), (-21.05) in the winter and the summer seasons, respectively.

These data are in agreement with the data reported by Katimon et al. (2004). who reported that ammonia level would give some indication on the amount of the residual agricultural materials transported into the drain. Also, Smedema and Rycroft (1983) recorded that, the N content would indicate the amount of nitrogen fertilizer leakage into the surface water.

\subsubsection{Phosphate (PO4- $\mathrm{P}$ )}

The removal rates of phosphate were high in summer and reached $(-21.7 \%)$ and $(-39.3 \%)$ in the two tested seasons. While, the rates were reduced in the winter $(-8.3 \%)$ and $(-55)$ in the two tested seasons respectively (Table 5 ).

The runoff from agricultural areas is a major contributor of phosphates in surface waters. Also, Municipal wastewater is another major source of phosphate in surface water (Water and Wastewater, 2000).

\subsection{Microbiological parameters}

\subsubsection{Total Microbial count}

The data presented in Fig. (7) show, the microbial counts at the winter and the summer seasons in the two years. The highest microbial counts were recorded at the summer in each of the two seasons. The counts reached $1.3-1.7 \times 10^{7}$ cfu $\mathrm{ml}^{-1}$ at the beginning of the drain. But, the counts were reduced and reached $13-17 \times 10^{4} \mathrm{cfu}$ $\mathrm{ml}^{-1}$ at the end of the drain, respectively.

While at winter season, the microbial counts 


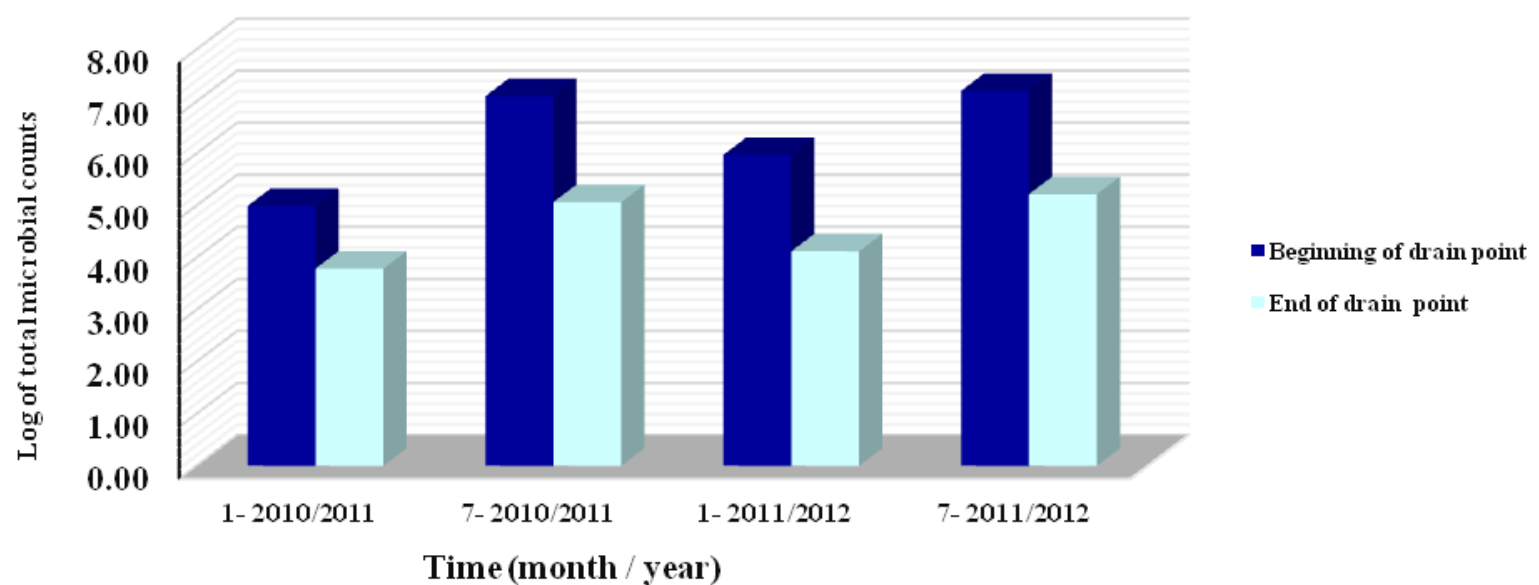

Fig. 7. Total microbial counts at the beginning and the end points of the drain during two years $2010 / 2011$ and $2011 / 2012$.

Table (3). Comparison between heavy metal concentrations and *Permissible limits in El-Gabbada drain at beginning point of the drain during two years 2010/2011 and 2011/2012.

\begin{tabular}{|c|c|c|c|c|c|c|}
\hline \multirow{2}{*}{ Month / Year } & \multicolumn{6}{|c|}{ Mean concentration of heavy metals at the beginning point of the drain } \\
\cline { 2 - 7 } & $\mathrm{Cu}$ & Mn & Cd & Zn & Fe & Total \\
\hline $1-2010 / 2011$ & $\mathbf{0 . 1 6}$ & $\mathbf{0 . 1 7}$ & $\mathbf{0 . 1 0}$ & $\mathbf{0 . 1 0}$ & $\mathbf{0 . 7 6}$ & 1.29 \\
\hline $7-2010 / 2011$ & $\mathbf{0 . 1 3}$ & $\mathbf{0 . 2 1}$ & $\mathbf{0 . 0 7}$ & $\mathbf{0 . 1 1}$ & $\mathbf{0 . 6 2}$ & 1.14 \\
\hline $1-2011 / 2012$ & $\mathbf{0 . 1 7}$ & $\mathbf{0 . 2 4}$ & $\mathbf{0 . 1 2}$ & $\mathbf{0 . 1 8}$ & $\mathbf{0 . 7 2}$ & 1.43 \\
\hline $7-2011 / 2012$ & $\mathbf{0 . 2 1}$ & $\mathbf{0 . 2 2}$ & $\mathbf{0 . 1 2}$ & $\mathbf{0 . 1 2}$ & $\mathbf{1 . 0 6}$ & 1.73 \\
\hline$*$ PL & 1.00 & $\mathbf{0 . 0 5}$ & $\mathbf{0 . 0 1}$ & $\mathbf{1 . 0 0}$ & $\mathbf{1 . 0 0}$ & \\
\hline
\end{tabular}

*PL= Permissible limits according of USEPA (1986).

Table (4). Comparison between heavy metals concentrations and *Permissible limits in El-Gabbada drain at end points of the drain during two years 2010/2011 and 2011/2012.

\begin{tabular}{|c|c|c|c|c|c|c|}
\hline \multirow{2}{*}{ Month / Year } & \multicolumn{5}{|c|}{ Mean concentration of heavy metals at the end of the drain } \\
\cline { 2 - 7 } & Cu & Mn & Cd & Zn & Fe & Total \\
\hline $1-2010 / 2011$ & $\mathbf{0 . 0 5}$ & 0.1 & 0.02 & 0.01 & $\mathbf{0 . 1 0}$ & 0.28 \\
\hline $7-2010 / 2011$ & 0.10 & 0.20 & 0.09 & 0.12 & 0.56 & 1.07 \\
\hline $1-2011 / 2012$ & 0.14 & 0.20 & 0.10 & 0.15 & 0.69 & 1.28 \\
\hline $7-2011 / 2012$ & 0.20 & 0.32 & 0.13 & 0.13 & 0.72 & 1.50 \\
\hline *PL & 1.00 & 0.05 & 0.01 & 1.00 & 1.00 & \\
\hline
\end{tabular}

*PL= Permissible limits according of USEPA (1986).

Table (5):Removal rate percentage for specific chemical compounds at the beginning and the end of ElGabbada drain during two years 2010/2011 and 2011/2012.

\begin{tabular}{|c|c|c|c|c|}
\hline & $\begin{array}{c}\text { Removal rate percentage at } \\
\text { the beginning and the end } \\
\text { of drain in January } \\
2010 / 2011\end{array}$ & $\begin{array}{c}\text { Removal rate percentage at } \\
\text { the beginning and the end } \\
\text { of drain in July 2011/2012 }\end{array}$ & $\begin{array}{c}\text { Removal rate percentage at } \\
\text { the beginning and the end } \\
\text { of drain in January } \\
2011 / 2012\end{array}$ & $\begin{array}{c}\text { Removal rate percentage at } \\
\text { the beginning and the end } \\
\text { of drain in July 2011/2012 }\end{array}$ \\
\hline $\mathrm{NO}_{3}$ & $\mathbf{- 3 8 . 0 0}$ & $-\mathbf{1 9 . 8 7}$ & $-\mathbf{2 1 . 4 5}$ & $\mathbf{0 5 . 1 8}$ \\
\hline $\mathrm{NH}_{4}$ & -92.86 & -19.23 & -24.00 & -21.05 \\
\hline $\mathrm{PO}_{4}$ & $-\mathbf{0 8 . 3 3}$ & -21.74 & $-\mathbf{5 5 . 0 0}$ & -39.29 \\
\hline
\end{tabular}


Table (6): Comparison between FC/FS Ratio estimated in El-Gabbada Drain at the beginning and the end points of the drain during the two years 2010/2011 and 2011/2012.

\begin{tabular}{|l|c|l|l|l|l|}
\hline \multirow{2}{*}{ Month/year } & \multicolumn{3}{|c|}{ Measurment } & \multicolumn{2}{c|}{ Standard reference } \\
\cline { 2 - 6 } & $\begin{array}{c}\text { Fecal } \\
\text { Colifor } \\
\mathrm{m}\end{array}$ & $\begin{array}{c}\text { Fesal } \\
\text { Strepto } \\
\text { cocci }\end{array}$ & $\begin{array}{c}\text { FC/FS } \\
\text { ratio }\end{array}$ & $\begin{array}{c}\text { FC/FS } \\
\text { Ratio } \\
\text { reference }\end{array}$ & Hollution \\
\hline January 2010/2011 & $\mathbf{1 5 1 . 5 0}$ & $\mathbf{3 5 . 0 0}$ & $\mathbf{4 . 3 3}$ & $>$ 4.0 & Human Pollution \\
\hline July 2010/2011 & $\mathbf{4 8 3 . 3 4}$ & $\mathbf{6 7 . 5 0}$ & $\mathbf{7 . 1 6}$ & $\mathbf{2 . 0 - 4 . 0}$ & Human waste in mixed pollution \\
\hline January 2011/2012 & $\mathbf{5 0 0 . 0 0}$ & $\mathbf{7 1 . 9 0}$ & $\mathbf{6 . 9 5}$ & $\mathbf{0 . 7 - 2 . 0}$ & Human waste in mixed pollution \\
\hline July 2011/2012 & $\mathbf{6 5 0 . 0 0}$ & $\mathbf{8 1 . 0 0}$ & $\mathbf{8 . 0 2}$ & $<\mathbf{0 . 7}$ & Animal pollution \\
\hline
\end{tabular}

were reduced compared with that recorded in summer and reached $1.1-11.0 \times 10^{5} \mathrm{cfu} \mathrm{ml}^{-1}$ at the beginning of drain. While, at the end of the drain, counts decreased and ranged between 7.0 -

$15.0 \times 10^{3} \mathrm{cfu} \mathrm{ml}^{-1}$, respectively.

The count was high at the beginning of the drain compared with the end point. The bacterial number increased in July than in January by $66 \%$ and $79 \%$ in the two seasons, respectively.

\subsubsection{Total coliform}

The results obtained about the total coliform counts recorded in the drain during the two seasons at both the beginning and the end of the drain are presented in Fig. (8).

The data revealed that, the counts were high at the summer in the two seasons at the beginning point of the drain. The numbers increased in July than January. The count was high at the beginning of the drain, then decreased at the end of the drain. The coliform counts reached $7.0-11.0 \times 10^{6} \mathrm{cfu}$ $\mathrm{ml}^{-1}$ drain water.

Bacteria are a potential pollutant where surface return flows come from land that has received applications of human or animal waste. Bacterial pollution may also originate from wetland discharges. The presence of coliform or fecal coliform would be an indication that other types of wastewater, such as municipal, industrial or animal waste, may have entered the surface drainage system (FAO, 1997).

\subsubsection{Fecal Coliform}

Fig. (9) shows the counts of fecal coliform estimated in the drain in the beginning and the end of the drain at the two year studies.

At the first, the counts were high at the beginning of the drain in summer time (700 to $1100 \mathrm{cfu} / \mathrm{ml}$ drain water), but at the end of the drain, the counts were decreased and reached 266.67 to $200 \mathrm{cfu} \mathrm{ml}$ drain water, respectively.

Also, as expected, the counts were high in the second year than in the first year due to winter clog. The counts high at July than January in both years. The decreased percentage in counts was due to temperature reached $(-48.5 \%)$ and $(-61.9 \%)$ in the $1^{\text {st }}$ year and $(-57.1 \%)$ and $(-81.8 \%)$ in the $2^{\text {nd }}$ year.

\subsubsection{Fecal Streptococci}

The counts of fecal streptococci in the drain in the two seasons and the two studied points showed that, the number was approximately in the same level and ranged between 63 to 78 cells $\mathrm{ml}$ water at the beginning of the drain. While, at the end of the drain, the fecal streptococci counts were reduced to $7-57$ cell $\mathrm{ml}$ water, respectively.

The counts in the second year (2011/2012) were high than in the $1^{\text {st }}$ year. Also, the fecal streptococci count increased in July than January irrespective of the year tested. The high removal rate was detected in January 2010/2011 and reached $92 \%$ followed by $27 \%$ in July in the same year (Fig.10). But, in the $2^{\text {nd }}$ year, the removal rate reached $(-28.3 \%)$ and $(-28.6 \%)$ in winter and summer time. The high removal rate in the $1^{\text {st }}$ year occurred due to the winter clog and decontamination wastes from the drain this was not true in the second year.

The comparison between fecal coliform and fecal streptococci FC/FS in the drain in the two studied years is presented in Table (6) (Gerba et $a l ., 2009)$. The results obtained revealed that the ratio between FC/FS was > 4.0. This means that, the drain was polluted by human waste. Also, the ratio was high in the second year than in the first year due to winter clog. In addition, FC/FS ratio increased in July than in January in both years, which might be due to increasing temperature during the summer season.

In conclusion, this study was designed to throw some light on wastewater quality samplings. Therefore, further research is needed to further verify the soil drainage- surface water quality relationship. These data would provide useful information towards an Integrated Wastewater Basin Management (IWBM) on the long run. To be more specific knowing the physical and chemical changes happening in the nearest field 


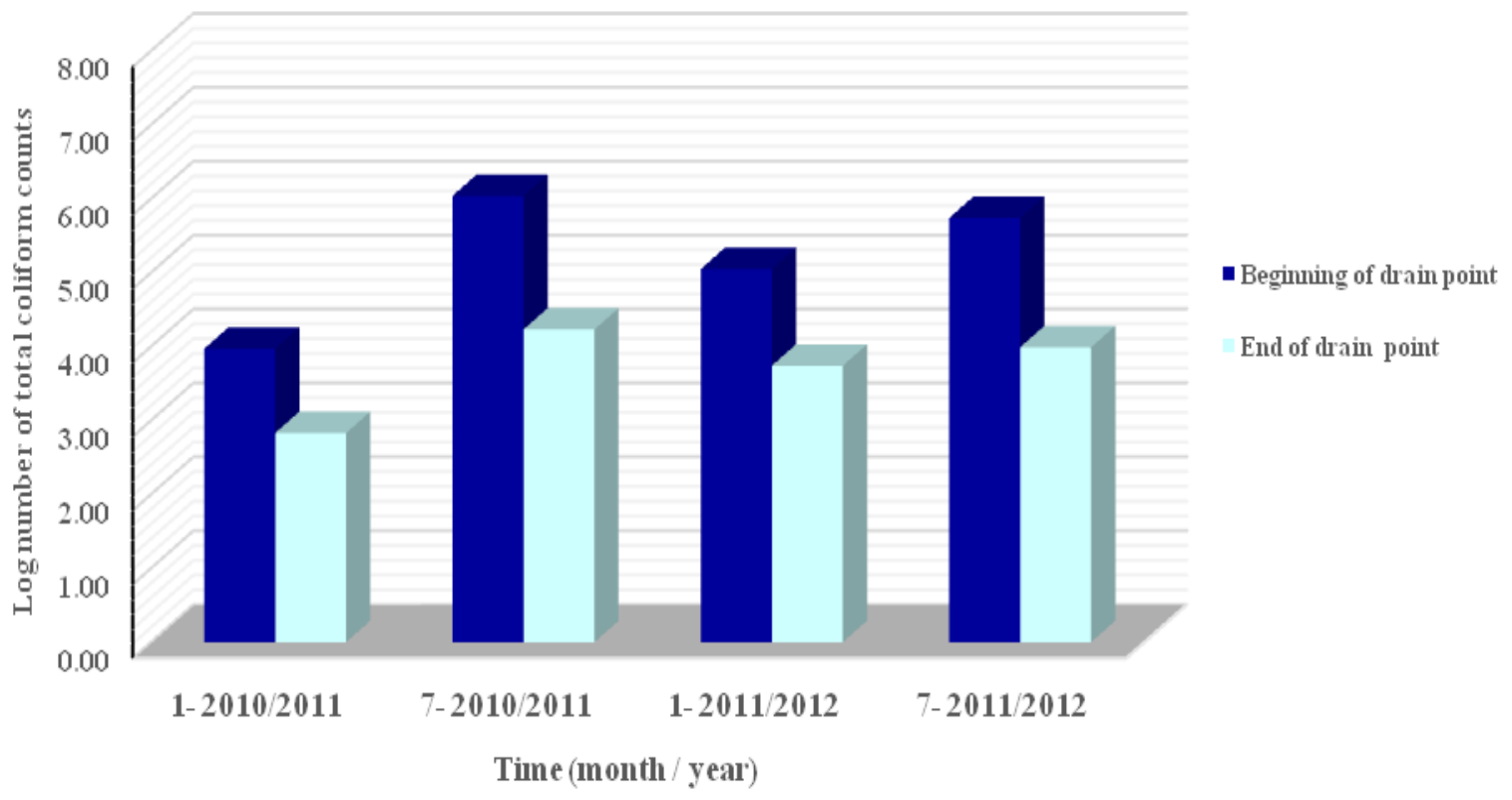

Fig.8. Total coliform counts at the beginning and the end points of the drain during two years $2010 / 2011$ and 2011/2012.

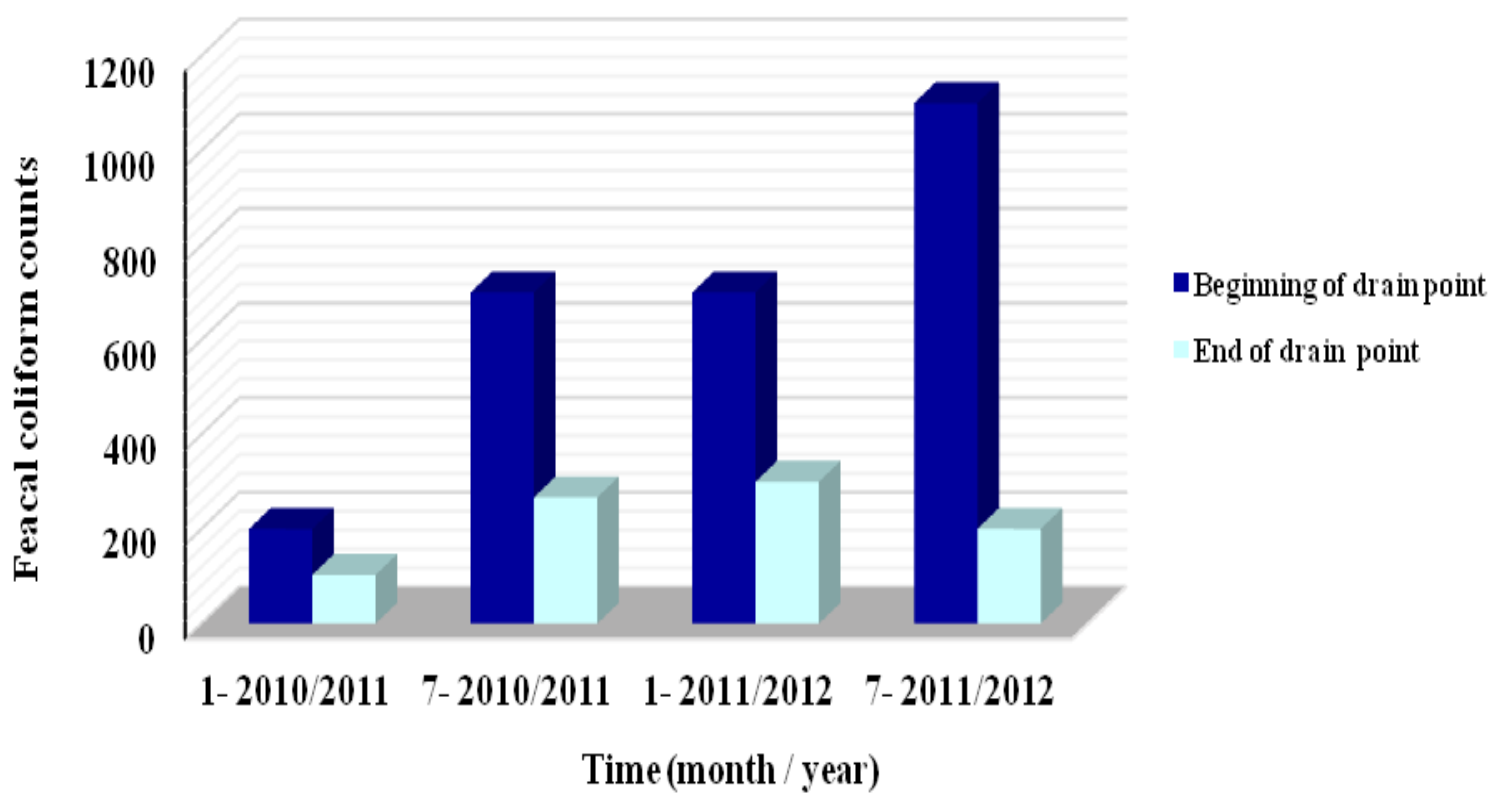

Fig.9. Feacal coliform counts estimated at the beginning and the end points the drain during two years 2010/2011 and 2011/2012. 


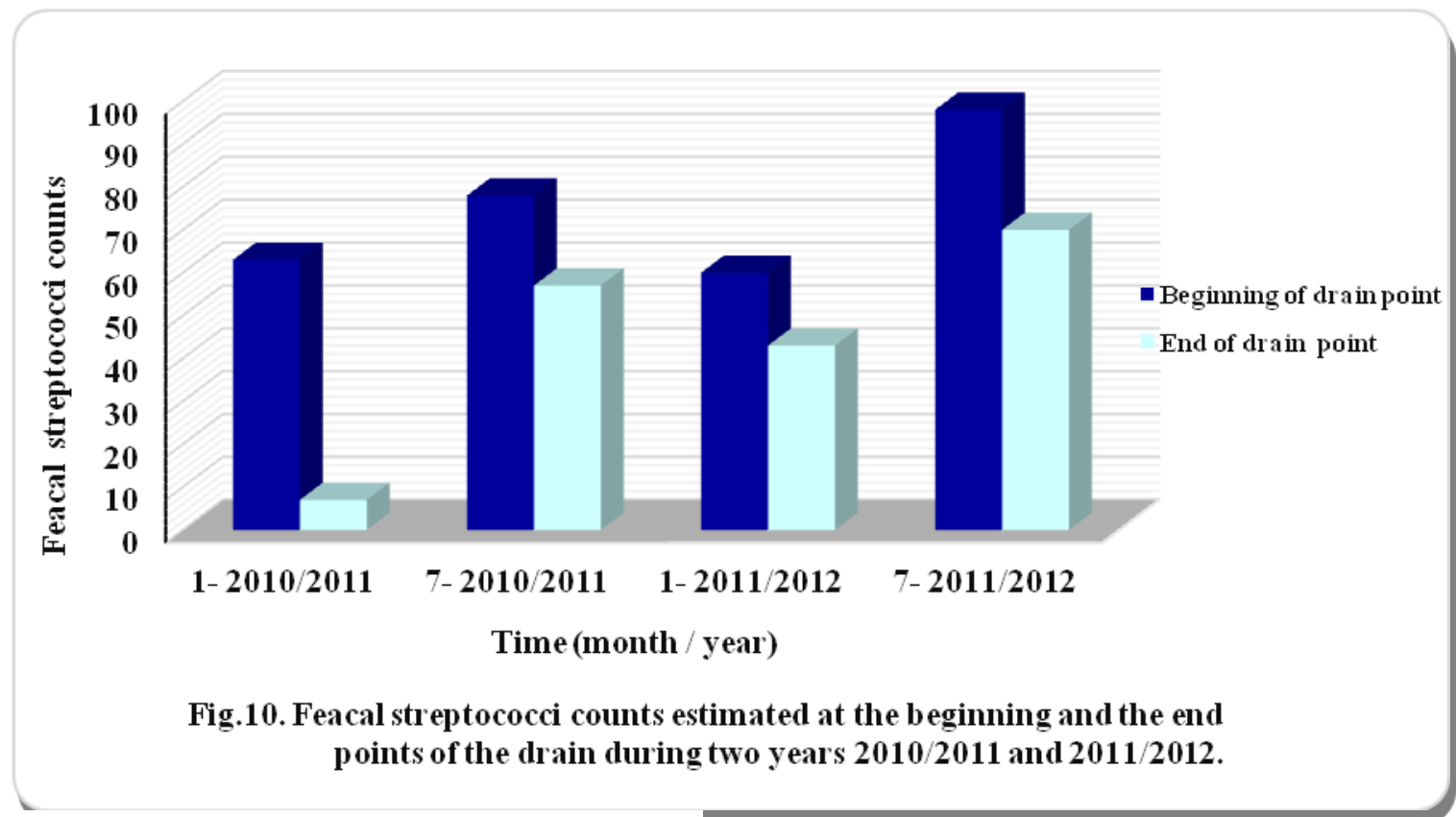

to the drain which would be able to predict the long term effects of soil chemical changes on wastewater quality parameters.

\section{REFERENCES}

Abdel -Azim R.A. and Allam M. (2004). Agricultural drainage water reuse in Egypt: strategic issues and mitigation measures. Faculty of Engineering, Department of Irrigation and Drainage Engineering. Cairo University, Egypt, pp. 93-103.

American Public Health Association "APHA" (1995). Standard methods for the examination of water and wastewater, Microbiological examination, Washington DC., USA, 46p.

Bull S. (2010). HPA Compendium of Chemical Hazards Cadmium.CRCE HQ, HPA, pp. 3-33.

Earth force (2010) .Water Quality Parameters, www.earthforce.org.

El-Sayed M. A., Beltagy A. I., Abou Nega W. M. and Halim Y. (1991). Role of humic substances in the accumulation of trace metals in bottom sediments. Bull. Natl. Inst. Oceangr. Fish. Egypt. 16: 239 - 254.

Encyclopaedia(2012,2013). www.en.wikipedia.org/wiki.

FAO (1997). Chapter 2 - Drainage water quality, California Regional Water Quality Control Board Sacramento, California, USA, 11p.

FAO (2005). Rapid assessment study towards integrated plannig of irrigation and drainage in Egypt, Final report, engineering perspective, Rome,181p. www.fao.org.

Gerba Charles P.,Maier Raina M. and Pepper Ian L. (2009). Environmental Microbiology,
Academic Press, chapter 23 indcator microorganisms. New York.598p.

IFA(2013).Sustainability,Cadmium. www.fertilizer.org.

Jafari N.G. and Trivedy R.K. (2005). Environmental pollution control by using phytoremediation technology. Pollution Research, 24 (4): 875-884.

Katimon A., Kassim A., Othman F., Sohaili J., Yusop Z. and Hashim N. (2004). Agriculture drainage affects river water quality. The Institution of Engineers, Malaysia ,65 (1-2):17.

KY OCP (2012). Types of bacteria used in wastewater treatment, kyocp.wordpress.com.

Mason C. F. (2002). Biology of freshwater pollution. 4 ed. Essex Univ. England. 387 p.

MOSS (2012). Dissolved Oxygen and Biological Oxygen Demand. McCall Outdoor Science School, Canada, 11p. www.uidaho.edu/cnr/moss

Nadask'a G., Lesnny J. and Michali'k. I. (2013). Environmental aspect of manganese chemistry, Dep. of Biotechnology, University of ss. Cyril and Methodius, J. Herdu 2, Trnava, SK-917 01, Slovakia.www.heja.szif.hu.

Padmavathi P. and Prasad M. K. D. (2007). Studies on algal bloom disasters in carp culture ponds. Braz. J. Morphol. Sci., 24(2): $32-43$.

Scott C., Faruqui N.I. and Raschid L. (2004). Wastewater use in irrigated agriculture. Confronting the livelihood and environmental realities. www.idrc.ca/en/ev.

Smedema L.K. and Rycroft D.W. (1983). Land 
Drainage. Cornel Univ, New York $376 \mathrm{p}$.

Trivedy R.K. (2001). Use of aquatic plants in wastewater treatment. In: Low Cost Wastewater Treatment Technologies. ABD publishers, Jaipur, pp.164-183.

USEPA (1986). Quality Criteria for Water. Office of water regulations and standards. Washington DC., USA, EPA 440 P.

USGS (2013).www.ga.water.usgs.gov.omics

Water and Wastewater (2000).

www.newagepublishers.com.

\section{دراسات ميكروبيولوجية وفيزوكيميائية على أحد المصارف الزراعية الفرعية بمحافظة الدقهلية \\ ماجدة مرضى أحمث* - جميل عبد الفتاح - محمد سيد خليل* ـ محمد زكريا صديق \\ قسم الميكروبيولوجيا الزراعية ـ كلية الزراعة ـ جامعة القاهرة و *جهاز شئون البيئة المصرى}

ملغص

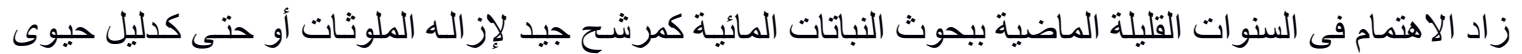

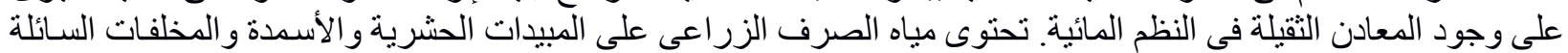

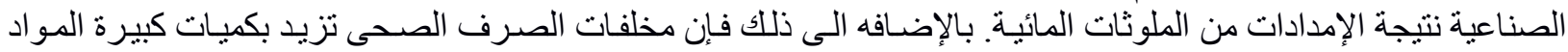

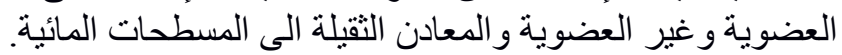

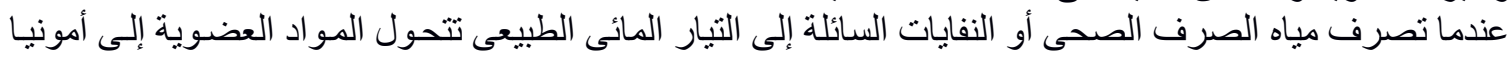

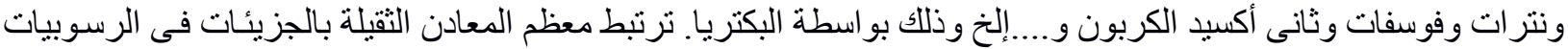

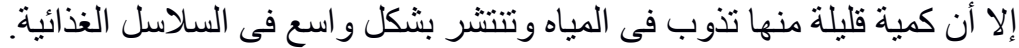

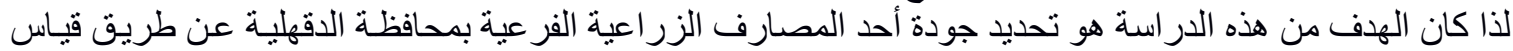

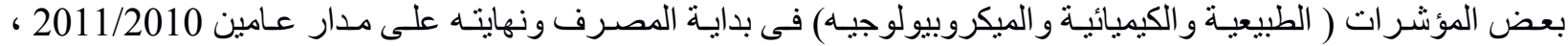

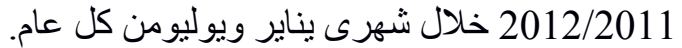

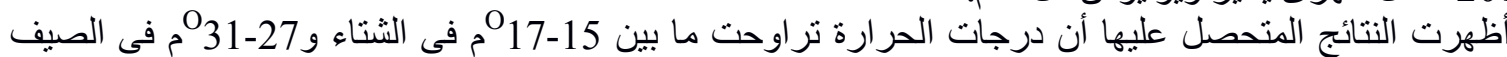

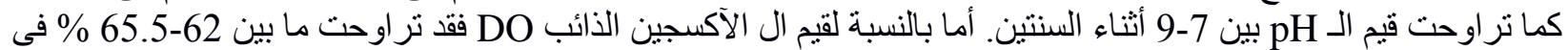

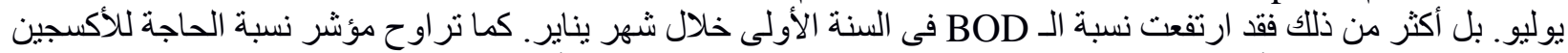
البيولوجى ب الحاجة للأكسيجين الكيماوى BOD/COD مابين

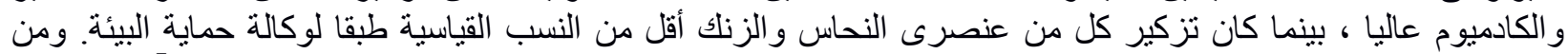

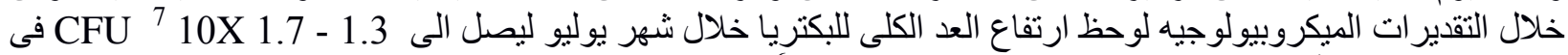

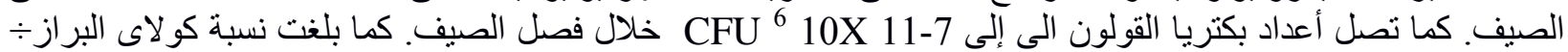

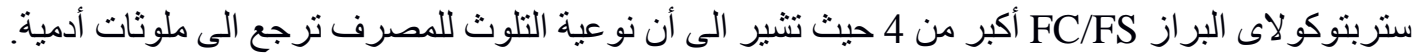

